\title{
Innovative English Classroom Teaching Based on Online Computer Technology in Rural Middle and Primary Schools
}

\author{
https://doi.org/10.3991/ijet.v13i10.9449 \\ Yan Gong \\ Baoji University of Arts and Sciences, Baoji, China \\ gongyan1100@163.com
}

\begin{abstract}
The rapid development of information technology and Internet technology has played a positive role in enriching classroom teaching forms and improving teaching effectiveness. To study the effects of the innovative English classroom teaching in rural primary and middle schools, this paper adopts the iterature analy-sis method, case study method and observation method, theoretically analyzes urban-rural distance teaching and establishes an urban-rural synchronous distance teaching model based on online computer technology. Then it gives detailed de-sign of the urban-rural synchronous distance teaching process based on online computer technology and uses a specific teaching case to investigate and analyze the effects of urban-rural synchronous distance teaching. The results prove that this teaching model can promote the effects of English classroom teaching in rural middle and primary schools, facilitate the urban-rural integrated teaching and en-riches the English classroom teaching froms in rural middle and primary schools.
\end{abstract}

Keywords - urban-rural synchronous distance teaching, urban-rural integration, teaching design, teaching effects

\section{Introduction}

At present, the basic education is not balanced in China. The problems are quite prominent in terms of the unevenly distributed urban and rural education resources and the poor quality of rural teachers, especially in English teaching. In rural areas, there are only a small number of English teachers, who have very different teaching abilities. The backward teaching methods and poor pronunciation have greatly affected the students in rural schools. Fortunately, information technology represented by computer technology and the Internet has made it possible for urban and rural areas to share education resources and for teachers and students to communicate with each other. The urban-rural integrated teaching now can be implemented.

Many countries in the world have used online computer technology to promote sharing of educational resources, enrich teaching forms, and realize distance learning. As early as 1886 , Japan formed a distance education model, while the United States mainly used the Internet as a medium to realize distance education and training [1]. MOOC is 
a synchronous distance education platform that has been widely used in recent years, but due to the lack of interactions, the teaching effects are not so good, and besides, many distance education platforms abroad focus on higher education, and few cases have been found in basic education [2].

The earliest synchronous classroom in China was based on television [3], but it only realized synchronous teaching progress without any exchange or interaction. In 2002, the application of satellite synchronous classroom brought synchronous distance teaching to people's attention, but it was seldom applied in basic education [4]. The rapid development of Internet technology has led to the rapid development of synchronous distance education based on network technology. Guangdong, Hebei, Anhui and other provinces have invested a great deal of manpower, material and financial resources in the IT-based education, applied information technology in urban-rural integrated teaching and obtained great results [5]. Meanwhile, many scholars have done a lot of research and practices on urban-rural interactive teaching, synchronous distance teaching and synchronous classroom, but these researches are still at the initial and experimental stage.

According to statistics, about $91 \%$ of primary and middle schools already have the capacity to use multimedia teaching equipment to conduct online learning [6]. Online computer technology can promote sharing of educational resources, deliver more educational resources to rural primary and middle schools and enrich the English classroom teaching forms in these schools.

Based on the above analysis, by summarizing and learning from domestic and foreign distance education models, this paper uses online computer technology to construct an urban-rural synchronous distance teaching model. Then with Lesson 10 of the English course in the fourth grade of primary school as an example, this paper provides detailed design of the innovative English classroom teaching based on online computer technology and analyzes the teaching effects of this model in terms of the video and audio transmission quality and teaching effect investigation. The results prove that the teaching model can achieve urban-rural integrated teaching, improve students' interest in learning, and enrich the English classroom teaching forms in rural primary and middle schools.

\section{Urban-rural synchronous distance teaching model based on online computer technology}

\subsection{Urban-rural synchronous distance teaching model}

Urban-rural synchronous distance teaching [7] is a form of teaching implemented based on distance education theory, education equity theory and social constructivist theory under the modern network technology environment for the purpose of sharing educational resources. In this teaching form, either an urban school or a rural school is taken as the main classroom and the other as the receiving classroom. Through network and multimedia technologies, the two teaching activities are finally implemented 
synchronously. Fig. 1 shows the urban-rural synchronous distance teaching model based on online computer technology [8].

In the urban-rural synchronous distance teaching model, either urban or rural school can serve as the main classroom for output of the course. Through this teaching mode, both sides can share their own featured course and teaching resources. Since English teachers at urban middle and primary schools have generally higher teaching levels and better pronunciation and teaching methods than the rural ones, this paper mainly takes the urban school as main teaching field for the urban-rural synchronous distance teaching model.



Fig. 1. Urban and rural synchronous education model based on computer online technology

\subsection{Components of the urban-rural synchronous distance teaching model based on online computer technology}

From the concept of urban-rural distance teaching, it can be known that it can be divided into the main classroom and the receiving classroom, as shown in Fig.2 [9]. The classrooms should be equipped with projectors that display the teaching courseware, as well as the main classroom and the receiving classroom, cameras used to film the students in the main classroom and the receiving classroom, microphones used by students to answer questions, multimedia computers and speakers [10]. The entire teaching model consists of the following four elements:

1. Leading teacher: the main implementer of the course task, who needs to design how to implement the course, lead the progress of the course and organize students to conduct classroom learning and discussions [11]. 
2. Teacher at the receiving end: responsible for assisting the leading teacher in completing the teaching task. Before the class, the teacher needs to communicate with the leading teacher to understand the entire teaching process; in the class, the teacher needs to maintain the order of the class at the receiving end and organize students to complete the course learning task; after the class, the teacher needs to understand how well students master the knowledge and give tutoring if necessary, and also communicate with the leading teacher about the learning status of the students so that the teaching plan can be adjusted in a timely manner.

3. Students in the main classroom: obeying and coordinating with the teaching activities of the leading teacher and taking on good attitudes to reduce the gaps with the students at the receiving end.

4. Students at the receiving end: following the arrangement by the teacher at the receiving end, actively participating in the teaching activities of the leading teacher, sharing learning experience with the teacher at the receiving end after class, and asking questions on difficult points.



Fig. 2. Primary and secondary classroom diagram of venue

\section{Practice of innovative English classroom teaching in rural middle and primary schools and teaching effect analysis}

In order to verify whether the urban-rural distance teaching model can help improve the effectiveness of English teaching in rural primary and middle schools, the author selected one urban primary school and one rural primary school in Hebei Province and 
conducted teaching design and implementation using Lesson 10 of the fourth-grade English course for primary school as an example. The author selected two classes and recorded their classroom teaching status and carried out questionnaire survey among the teachers and students involved in the experiment [12]. Then the author summarized and analyzed the observations and survey results and reached the conclusions.

\subsection{Teaching design for the urban-rural synchronous distance teaching case}

In the urban-rural synchronous distance teaching design with the urban school as the main teaching field, the urban teacher, as the leading teacher, should consider not only the learning situation of local students, but also the differences between rural and urban students in learning methods and progress when designing the teaching plan, especially when designing the interactive part of the teaching activity [13], in which case, the teacher should motivate the enthusiasm of the students on both sides through appropriate ways. Figure 3 shows the process where students on both sides ask questions to each other using projection and whiteboard. Based on the analysis of the students' learning status, the author appropriately reduced the amount of vocabulary task and decided to take the application of the sentence pattern "what do you do in the morning?" as the teaching objective. Before class, the leading teacher will give students a picture depicting the things to do in the morning after getting up, and in the class, the teacher will ask the students to describe the picture in English. The teacher will also use PPT courseware and audio reading materials as supporting teaching resources [14] to complete the teaching. After the class, the teacher will assign homework to the students. The teaching evaluation consists of teacher evaluation, self-evaluation, and student peer review [16]. Table 1 shows the designed teaching process of this lesson.



Fig. 3. Students ask each other through projection and whiteboard 
Table 1. English teaching process

\begin{tabular}{|l|l|l|l|}
\hline Teaching session & \multicolumn{1}{|c|}{ Teacher behavior } & \multicolumn{1}{c|}{ Student behavior } & \multicolumn{1}{c|}{ Activity target } \\
\hline Course import & Teacher asks both students & $\begin{array}{l}\text { Students answer ques- } \\
\text { tions and show their } \\
\text { work }\end{array}$ & $\begin{array}{l}\text { Attract students' attention } \\
\text { and make it easy for both stu- } \\
\text { dents }\end{array}$ \\
\hline Teachers show & $\begin{array}{l}\text { Teachers show PPT } \\
\text { courseware, play recordings, } \\
\text { teachers read }\end{array}$ & Students read the word & $\begin{array}{l}\text { Master the pronunciation and } \\
\text { spelling of new words }\end{array}$ \\
\hline $\begin{array}{l}\text { Import sentence } \\
\text { pattern }\end{array}$ & $\begin{array}{l}\text { The teacher plays the anima- } \\
\text { tion, eliciting sentences }\end{array}$ & $\begin{array}{l}\text { Students read and act ac- } \\
\text { cordingly }\end{array}$ & $\begin{array}{l}\text { Make students familiar with } \\
\text { sentence patterns }\end{array}$ \\
\hline Group competition & $\begin{array}{l}\text { Both groups of students con- } \\
\text { duct connection games }\end{array}$ & $\begin{array}{l}\text { Students actively raise } \\
\text { their hands to participate } \\
\text { in the contest }\end{array}$ & $\begin{array}{l}\text { Inspire students' interest in } \\
\text { learning and deepen their } \\
\text { memory }\end{array}$ \\
\hline Class test & $\begin{array}{l}\text { Both classmates answer ques- } \\
\text { tions on the electronic white- } \\
\text { board }\end{array}$ & $\begin{array}{l}\text { Students answer ques- } \\
\text { tions by listening to the } \\
\text { recording }\end{array}$ & $\begin{array}{l}\text { Deepen the memory of words } \\
\text { and sentences }\end{array}$ \\
\hline $\begin{array}{l}\text { Teachers summa- } \\
\text { rize the assign- } \\
\text { ment }\end{array}$ & $\begin{array}{l}\text { Teachers summarize what } \\
\text { they have learned and arrange } \\
\text { assignments }\end{array}$ & $\begin{array}{l}\text { Follow teacher's thinking } \\
\text { to comb the knowledge } \\
\text { learned }\end{array}$ & $\begin{array}{l}\text { Summarize the course and } \\
\text { evaluate students }\end{array}$ \\
\hline
\end{tabular}

\subsection{Analysis of the urban-rural synchronous distance teaching effects}

\section{Video and audio transmission quality}

Table 2. Video, audio quality class record table

\begin{tabular}{|c|c|c|c|c|c|c|c|c|c|c|c|c|}
\hline \multirow{3}{*}{ Time } & \multicolumn{6}{|c|}{ Main site video and audio transmission } & \multicolumn{6}{|c|}{ Vice venue video and audio transmission } \\
\hline & \multicolumn{2}{|c|}{\begin{tabular}{|c|} 
Whether \\
the video is \\
smooth
\end{tabular}} & \multicolumn{2}{|c|}{$\begin{array}{l}\text { Whether } \\
\text { the audio } \\
\text { is smooth }\end{array}$} & \multicolumn{2}{|c|}{$\begin{array}{l}\text { Whether video } \\
\text { and audio are } \\
\text { synchronized }\end{array}$} & \multicolumn{2}{|c|}{$\begin{array}{c}\text { Whether the } \\
\text { video is } \\
\text { smooth }\end{array}$} & \multicolumn{2}{|c|}{$\begin{array}{c}\text { Whether the } \\
\text { audio is } \\
\text { smooth }\end{array}$} & \multicolumn{2}{|c|}{$\begin{array}{l}\text { Whether video } \\
\text { and audio are } \\
\text { synchronized }\end{array}$} \\
\hline & $F$ & $S$ & $F$ & $S$ & $F$ & $S$ & $F$ & $S$ & $F$ & $S$ & $F$ & $S$ \\
\hline $1-3$ & & $\sqrt{ }$ & $\sqrt{ }$ & & $\sqrt{ }$ & $\sqrt{ }$ & $\sqrt{ }$ & $\sqrt{ }$ & $\sqrt{ }$ & $\sqrt{ }$ & $\sqrt{ }$ & $\sqrt{ }$ \\
\hline $4-6$ & $\sqrt{ }$ & $\sqrt{ }$ & $\sqrt{ }$ & $\sqrt{ }$ & $\sqrt{ }$ & $\sqrt{ }$ & $\sqrt{ }$ & $\sqrt{ }$ & & $\sqrt{ }$ & & $\sqrt{ }$ \\
\hline $7-9$ & $\sqrt{ }$ & $\sqrt{ }$ & & $\sqrt{ }$ & & $\sqrt{ }$ & & $\sqrt{ }$ & $\sqrt{ }$ & $\sqrt{ }$ & & $\sqrt{ }$ \\
\hline $10-12$ & & $\sqrt{ }$ & $\sqrt{ }$ & $\sqrt{ }$ & & $\sqrt{ }$ & $\sqrt{ }$ & $\sqrt{ }$ & $\sqrt{ }$ & $\sqrt{ }$ & $\sqrt{ }$ & $\sqrt{ }$ \\
\hline $13-15$ & $\sqrt{ }$ & $\sqrt{ }$ & $\sqrt{ }$ & $\sqrt{ }$ & $\sqrt{ }$ & $\sqrt{ }$ & & $\sqrt{ }$ & $\sqrt{ }$ & $\sqrt{ }$ & & $\sqrt{ }$ \\
\hline $16-18$ & $\sqrt{ }$ & $\sqrt{ }$ & $\sqrt{ }$ & $\sqrt{ }$ & $\sqrt{ }$ & $\sqrt{ }$ & $\sqrt{ }$ & $\sqrt{ }$ & $\sqrt{ }$ & $\sqrt{ }$ & $\sqrt{ }$ & $\sqrt{ }$ \\
\hline $19-21$ & $\sqrt{ }$ & $\sqrt{ }$ & $\sqrt{ }$ & $\sqrt{ }$ & $\sqrt{ }$ & $\sqrt{ }$ & $\sqrt{ }$ & $\sqrt{ }$ & $\sqrt{ }$ & $\sqrt{ }$ & $\sqrt{ }$ & $\sqrt{ }$ \\
\hline $22-24$ & $\sqrt{ }$ & $\sqrt{ }$ & & $\sqrt{ }$ & & $\sqrt{ }$ & $\sqrt{ }$ & $\sqrt{ }$ & $\sqrt{ }$ & $\sqrt{ }$ & $\sqrt{ }$ & $\sqrt{ }$ \\
\hline $25-27$ & $\sqrt{ }$ & $\sqrt{ }$ & $\sqrt{ }$ & $\sqrt{ }$ & $\sqrt{ }$ & $\sqrt{ }$ & $\sqrt{ }$ & $\sqrt{ }$ & & $\sqrt{ }$ & & $\sqrt{ }$ \\
\hline $28-30$ & & $\sqrt{ }$ & $\sqrt{ }$ & $\sqrt{ }$ & & $\sqrt{ }$ & $\sqrt{ }$ & $\sqrt{ }$ & $\sqrt{ }$ & $\sqrt{ }$ & $\sqrt{ }$ & $\sqrt{ }$ \\
\hline $31-33$ & $\sqrt{ }$ & $\sqrt{ }$ & $\sqrt{ }$ & $\sqrt{ }$ & $\sqrt{ }$ & $\sqrt{ }$ & $\sqrt{ }$ & & $\sqrt{ }$ & $\sqrt{ }$ & $\sqrt{ }$ & \\
\hline $34-36$ & & $\sqrt{ }$ & $\sqrt{ }$ & $\sqrt{ }$ & & $\sqrt{ }$ & & $\sqrt{ }$ & $\sqrt{ }$ & $\sqrt{ }$ & & $\sqrt{ }$ \\
\hline $37-39$ & $\sqrt{ }$ & & $\sqrt{ }$ & & $\sqrt{ }$ & & $\sqrt{ }$ & $\sqrt{ }$ & $\sqrt{ }$ & $\sqrt{ }$ & $\sqrt{ }$ & $\sqrt{ }$ \\
\hline $40-42$ & $\sqrt{ }$ & $\sqrt{ }$ & $\sqrt{ }$ & $\sqrt{ }$ & $\sqrt{ }$ & $\sqrt{ }$ & $\sqrt{ }$ & $\sqrt{ }$ & $\sqrt{ }$ & $\sqrt{ }$ & $\sqrt{ }$ & $\sqrt{ }$ \\
\hline $43-45$ & $\sqrt{ }$ & $\sqrt{ }$ & $\sqrt{ }$ & $\sqrt{ }$ & $\sqrt{ }$ & $\sqrt{ }$ & $\sqrt{ }$ & $\sqrt{ }$ & & $\sqrt{ }$ & & $\sqrt{ }$ \\
\hline Proportion \% & 73 & 92 & 86 & 93 & 60 & 92 & 80 & 93 & 79 & 100 & 60 & 93 \\
\hline
\end{tabular}

*F here represents first round; $\mathrm{S}$ here represents second round. 
The smooth and clear video and audio transmission is the prerequisite for the successful implementation of the urban-rural synchronous distance teaching [16] and also the most basic requirement for guaranteeing the effect of classroom teaching. Therefore, the author recorded the quality of video and audio transmission in classroom teaching, as shown in Table 2.

According to regular observation, in the two experimental classes with the urban school as the main teaching field, the time of smooth video and audio transmission took up more than $73 \%$ of the whole class time in the urban classroom, and over $80 \%$ in the rural classroom, which basically met the teaching requirements, but the video and audio synchronization time in the first experimental class only accounted for $60 \%$ of the whole class time, a lot less than the percentage $93 \%$ in the second experimental class, as shown in Fig.4 and Fig.5. This shows that the video and audio synchronization problem need to be further addressed in the urban-rural distance teaching; otherwise, it will affect the effects of classroom teaching.



Fig. 4. Main site video and audio transmission changes

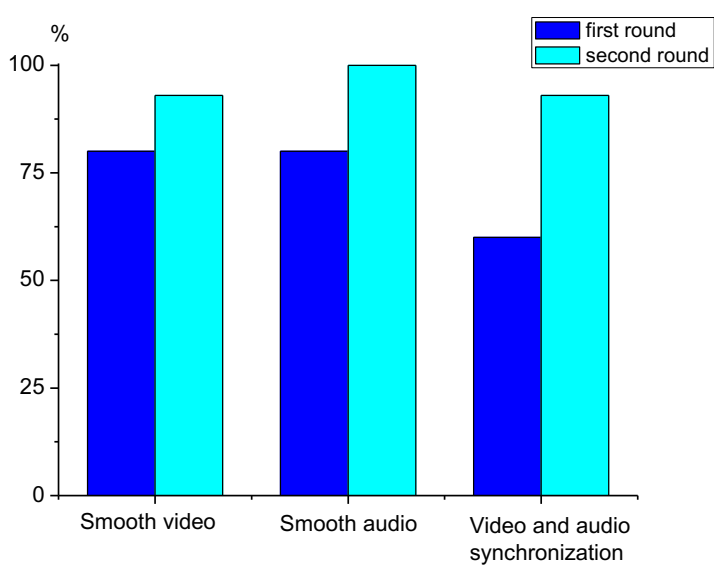

Fig. 5. Vice venue video and audio transmission changes 
Interactions between teachers and students. Table 3 records the teacher-student interactions in the main and receiving classrooms in the urban-rural synchronous distance teaching. It can be seen that the leading teacher tutored individual students in the main classroom for 3 and 4 times, respectively, while the teacher in the receiving classroom gave 0 tutoring. This shows that teachers at the receiving end should improve their tutoring in the urban-rural distance teaching. In terms of students answering teachers' questions, the students on both sides had similar performance, but overall, urban students answered more questions. In addition, in terms of raising hands, rural students were more active than urban ones, indicating that rural students have great enthusiasm for this learning model, but as it was distance teaching, they got few chances to answer the questions. Therefore, in the future teaching process, teachers should balance and coordinate the participation rates of the students in urban and rural areas in order not to discourage rural students [17].

Table 3. Teacher-student interaction level record

\begin{tabular}{|l|c|c|c|c|}
\hline \multirow{2}{*}{\multicolumn{2}{c|}{ Interaction situation }} & \multicolumn{2}{c|}{ The main venue } & \multicolumn{2}{c|}{ Vice venue } \\
\cline { 2 - 5 } & First round & Second round & First round & Second round \\
\hline Number of tutoring students individually & 3 & 4 & 0 & 0 \\
\hline Students answer teacher questions & 38 & 33 & 26 & 27 \\
\hline Number of student teacher questions & 27 & 24 & 25 & 22 \\
\hline The number of students raising their hands & 985 & 789 & 1022 & 853 \\
\hline
\end{tabular}

Questionnaire on the teaching effects of urban-rural interactive teaching on rural students

Whether the students like this class. From the survey results in Fig.6, it can be seen that $89 \%$ of the students expressed their preference for this kind of urban-rural interactive teaching mode. They believed that urban teachers taught more interesting content and used better methods than rural teachers, and $85 \%$ of students expressed that they would like to receive this kind of teaching again in the future.

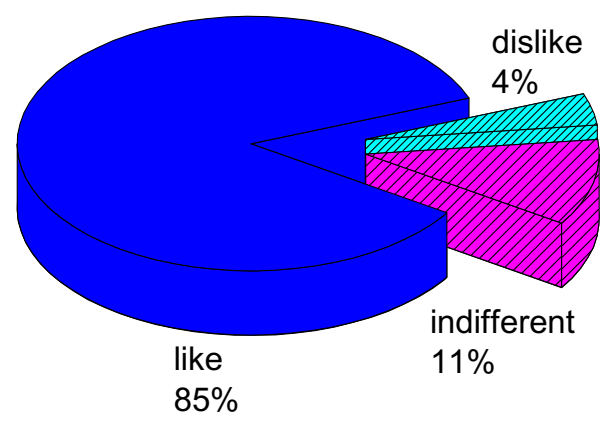

Fig. 6. Do you like today's class?

Whether there is any change in their interest. Regarding the question of whether the urban-rural distance teaching has any influence on your interest in learning, the survey 
results show that $70 \%$ of students thought that they were more interested in this learning model and that only $11 \%$ of them believed that such learning model would diminish their learning interest, as shown in Fig.7. This is probably because these students did not get used to communicating with the teacher across the screen or felt that they got few chances to participate in the classroom interaction, but most students indicated that this teaching model could improve the activity level of the class and increase their learning interest.



Fig. 7. Whether learning interest changes

\section{Conclusions}

This paper attempts to study the effects of innovative English classroom teaching based on online computer technology. Through research and analysis of related literatures at home and abroad, this paper establishes an urban-rural synchronous distance teaching model based on online computer technology. The specific conclusions are as follows:

1. On the basis of the theoretical research on urban-rural distance teaching, this paper establishes an urban-rural synchronous distance teaching model based on online computer technology and describes its components in detail.

2. According to the urban-rural synchronous distance teaching model, it designs the detailed teaching process for the English course at the fourth grade in primary school, and implements this process to verify the teaching effect of the model.

3. According to the teaching case and the investigation results of the classroom and post-class teaching effects, this model is proved to have good teaching effects and can promote the enthusiasm of the students in rural middle and primary schools in learning English. 


\section{$5 \quad$ Acknowledgments}

Special planning project in Educational Department of Shaanxi Provincial Government; Planning project of Shaanxi educational science "the 13th Five-Year Plan" (SGH17H268); Scientific research project of education reform in Baoji University of Arts and Sciences (JGYB15043).

\section{References}

[1] Chen, H. Y., \& Liu, K. Y. (2008). Web-based synchronized multimedia lecture system design for teaching/learning chinese as second language. Computers \& Education, 50(3), 693702.https://doi.org/10.1016/j.compedu.2006.07.010

[2] Anıl, Ö., Batd1, V., \& Küçüközer, H. (2018). The effect of computer-supported educa-tion on student attitudes: A meta-analytical comparison for the period 2005-2015. Educational Sciences: Theory \& Practice, 18(1), 5-22.https://doi.org/10.12738/estp.2018.1.0285

[3] Karakas, E., \& Tekindal, S. (2008). The effects of computer-assisted learning in teach-ing permanent magnet synchronous motors. IEEE Transactions on Education, 51(4), 448455.https://doi.org/10.1109/TE.2007.912546

[4] Pullen, J. M., \& Benson, M. (1999). Classwise: synchronous internet desktop educa-tion. IEEE Transactions on Education, 42(4), 19 pp.https://doi.org/10.1109/13.804562

[5] Yeh, K. H., \& She, H. C. (2010). On-line synchronous scientific argumentation learn-ing: nurturing students' argumentation ability and conceptual change in science con-text. Computers \& Education, 55(2), 586-602.https://doi.org/10.1016/j.compedu.2010.02.020

[6] Snow, C., Pullen, J. M., \& Mcandrews, P. (2005). Network educationware: an open-source web-based system for synchronous distance education. IEEE Transactions on Education, 48(4), 705-712.https://doi.org/10.1109/TE.2005.854577

[7] Warschauer, M., Shetzer, H., \& Meloni, C. (1997). Internet for english teaching. Sys-tem, 29(3), 419-426.

[8] $\mathrm{Wu}, \mathrm{Y}$. (2001). English language teaching in china: trends and challenges. Tesol Quar-terly, 35(1), 191-194.https://doi.org/10.2307/3587867

[9] Pica, T. (2000). Tradition and transition in english language teaching methodology 1 . System, 28(1), 1-18.https://doi.org/10.1016/S0346-251X(99)00057-3

[10] Gonzálezpueyo, I. (2010). Teaching academic and professional english online. System, 38(3), 508-510.https://doi.org/10.1016/j.system.2010.06.007

[11] Olga Kozar. (2012). Use of synchronous online tools in private english language teaching in russia. Distance Education, 33(3), 415-420.https://doi.org/10.1080/0158791 9.2012.723164

[12] Jarvis, H. (2006). Issues of computer-mediated communication for english language teaching. British Journal of Educational Technology, 37(4), 643-645.https://doi.org/10.1111/j.1 467-8535.2006.00592.x

[13] Edwards, R. A., Kirwin, J., Gonyeau, M., Matthews, S. J., Lancaster, J., \& Divall, M. (2014). A reflective teaching challenge to motivate educational innovation. American Journal of Pharmaceutical Education, 78(5), 103.https://doi.org/10.5688/ajpe785103

[14] Selwyn, N. (2007). The use of computer technology in university teaching and learn-ing: a critical perspective. Journal of Computer Assisted Learning, 23(2), 8394.https://doi.org/10.1111/j.1365-2729.2006.00204.x 
Paper-Innovative English Classroom Teaching Based on Online Computer Technology in Rural Middle...

[15] Hathorn, L., \& Hathorn, J. (2010). Evaluation of online course websites: is teaching online a tug-of-war?. Journal of Educational Computing Research, 42(2), 197217.https://doi.org/10.2190/EC.42.2.d

[16] Kılıçkaya, F. (2015). Computer-based grammar instruction in an efl context: improv-ing the effectiveness of teaching adverbial clauses. Computer Assisted Language Learning, 28(4), 325-340.https://doi.org/10.1080/09588221.2013.818563

[17] Zhao, H., \& Sullivan, K. P. H. (2017). Teaching presence in computer conferencing learning environments: effects on interaction, cognition and learning uptake. British Journal of Educational Technology, 48(2), 538-551.https://doi.org/10.1111/bjet.12383

\section{$7 \quad$ Author}

Yan Gong, (1981-), female, lecturer, master degree, main research direction: English teaching and English translation. She is with the School of Foreign Languages, Baoji University of Arts and Sciences, Baoji 721013, China.

Article submitted 31 August 2018. Resubmitted 10 September 2018. Final acceptance 23 September 2018. Final version published as submitted by the author. 